\title{
Application of IPA in Service Quality for National University Sport Games in Taiwan
}

\author{
Hui-Chen Lee*, Mei-Fang Chen \\ Graduate School of Leisure and Exercise Studies, National Yunlin University of Science and Technology, Taiwan
}

Copyright (C) 2015 by authors, all rights reserved. Authors agree that this article remains permanently open access under the terms of the Creative Commons Attribution License 4.0 International License

\begin{abstract}
The purpose of the study was to explore the perspectives of athletes who participated in the National University Sport Games in Taiwan regarding to the service quality with 308 valid subjects. Importance-performance analysis was used to discover the service quality; the questionnaire was formed to understand the needs and feelings of participants, in order to help managers to provide better service quality. The result of the study was indicated that thirteen items, those were both high in importance and performance, in which must keep; in the meanwhile, there were four questions in high importance and low in performance, in which must be in the first priority to improve to enhance service quality and increase participants' satisfaction. According to the result, managerial recommendations were discussed and suggestion for further researches also mentioned.
\end{abstract}

Keywords National University Sport Games Importance-performance Analysis, Service Quality

\section{Introduction}

To achieve a good outcome for sport competitions, event manages always plan how to understand the needs of sport event participants, in order to offer good programs to reach participants' expectation as well as increases service quality. Service quality was the premise of customer satisfaction (Cronin \& Taylor, [1]; Oliver, [2]; Spreng \& MacKoy, [3]), providing the services to reach the expectations of participants and also would raise their satisfaction and enhance future participation (Baker \& Crompton, [4]; Cronin, Brady \& Hult, [5]; Petrick, [6]; Baloglu, [7]; Bigne et al., [8]; Petrick, Morais \& Norman, [9]), in which would be managers mainly concern. Therefore, the purpose of the study was to understand the expectations of participants in service quality for National University Sport Games in Taiwan, the biggest sport event for collegiate athletes which is held every year with different host university or college, and provide the information to event managers of the organization to improve service quality to increase participants' satisfaction.

\subsection{Service quality}

Service quality was defined the customers' comparison between service expectation and service performance (Grönroos, [10]; Lewis \& Booms, [11]; Parasuraman, Zeithaml \& Berry, [12]; Woodside, Frey \& Daly, [13]; Bolton \& Drew, [14]; Shonk \& Chelladurai, [15]; Caruana et al., [16]; Lehtinen \& Lehtinen, [17]; Gronroos, [18]). Lewis and Vincent [19] believed that service quality has to fulfill the need of the customers. In addition, Tang and Hu [20] thought that service quality was from the customers' point of view to satisfy the customers. There were studies indicated that perception of service quality would affect customers' feeling of satisfaction, and influence future intention to products or services (Alexandris et al., [21]; Bernhardt et al.,[22]; Ganesh et al., [23]; Howat et al.,[24]; Murray \& Howat, [25]; Voss et al., [26]). As the mention above, if customers' perception of service quality performance was higher than expectation, they would satisfied with the service quality; on the other hand, vice versa, they would be unsatisfied when performance of service was lower than expectation (Lu, Chang \& Huang, [27]). According the literature, many sport organization or association would try to utilize with service quality to understand the demands or expectations to satisfied customers, and also assist the organizations to reach the element of success (Tsitskari, Tsiotras \& Tsiotras, [28]; Ko \& Pastore, [29]); for examples, there were studies had been done in service quality for sport events resulted in service quality would positively increase participants' consumer satisfaction (Tsuji, Bennett \& Zhang, [30]), perceived value, and future intention (Moon, Ko, Connaughton \& Lee, [31]).

\subsection{Importance-performance Analysis}

Importance-performance analysis (IPA) was first mentioned by Martilla and James [32] that the results of average of each item can be graphically displayed and easily 
interpreted in two-dimensional grid with label of four quadrants for further marketing strategy decisions. Haemoo [33] discovered that IPA can assist customers to consider those factors before purchasing products or services. IPA was not the only research method, but also can help customers to distinguish what is the factors of products, services or sells; furthermore, IPA is a good management tool for receiving advantages and increasing market opportunities (Chapman, [34]; Cheron et. al., [35]; Raymond \& Chu, [36]).

Marr [37] applied IPA in customer-based quality measurement, to retrieve customers' view of service importance and performance data, and then displayed in importance-performance analysis grid, to help managers to improve service quality of firms. IPA was formed in the four quadrants (Marr, [37]; Martilla \& James, [32]), please see figure 1.

1.1.1. Quadrant I, keep up with the good work: customers require high in importance and the service also in high performance, in which means the execution of the service fulfilled satisfaction.

1.1.2. Quadrant II, concentrate here: customers need high importance in service, but low in performance, thus, the unit has to improve the service to increase customers' satisfaction.

1.1.3. Quadrant III, low priority: customers need the service is low importance, and the unit also does in low performance, in which implies that there is minor pressure for improvement.

Quadrants IV, possible overkill: low importance in the portion, however, the unit has high performance, in which means that the unit offers too much resource in the section, and the unit should reduce resources in it.

According to IPA four quadrants, the unit managers should focus on quadrant I and II, because those addressed in high importance, representing the voice of customers; in other words, if the unit performed well in those services to satisfy the needs of customers, and they will be pleased and presented with loyalty. This is the way to assist the firm to run the business sustainably.

\begin{tabular}{|c|c|c|}
\hline \multirow{3}{*}{ Importance } & $\begin{array}{c}\text { Quadrant II Concentrate } \\
\text { here (High Importance/ } \\
\text { Low Performance) }\end{array}$ & $\begin{array}{c}\text { Quadrant I Keep up the } \\
\text { good work (High } \\
\text { Importance/ High } \\
\text { Performance) }\end{array}$ \\
\cline { 2 - 3 } & $\begin{array}{c}\text { Quadrant III Low priority } \\
\text { (Low Importance/ Low } \\
\text { Performance) }\end{array}$ & $\begin{array}{c}\text { Quadrant IV Possible } \\
\text { overkill (Low Importance/ } \\
\text { High Performance ) }\end{array}$ \\
\hline & \multicolumn{2}{|c|}{ Performance } \\
\hline
\end{tabular}

Resource: Martilla, J. A. and James, J. C. (1977). Importance - Performance Analysis. Journal Marketing, 41(1), 77-79.

Figure 1. Importance-Performance Analysis (IPA)

\subsection{Purpose of the Research}

According to the literature review, service quality is widely used to different fields and also in sport industry; for example, marathon from $\mathrm{Lu}$ and Chen [38], the results indicated that "quality of activities" and "quality of achievements" can predict re-participation of runners; Chung [39] in National Universidad Sports Games, service quality would positively affect behavioral intention of participants; cycling competition from Chen, Chen and Lee [40] displayed that service quality would positively affect satisfaction, and indirectly influence behavioral intention of participants through satisfaction; those researches used the feelings of participants after experiences. In addition, in the review of literature, IPA applied to many fields for studies, such as, visits' satisfaction in heritage tourism (Chang, Lai, \& Wang, [41]), service quality at the museum of contemporary art (Liao, [42]), teaching quality (Ho, Chung, \& Chang, [43]), e-commerce strategies (Levenburg \& Magal, [44]); however, the IPA was seldom applied for service quality in sport competition, importance is addressed in the thought of participants before participation and satisfaction (performance) after experiences. Thus, the purpose of the study wanted to use IPA for the National University Sport Games in Taiwan, to assist sport event managers to understand the expectations of participants' views of service quality attributes, and how their satisfaction after experiences, in order to help event managers to improve sport games service quality to increase satisfaction in the future, and also enrich the academic studies in the sport industry.

\section{Method}

\subsection{Sample}

The sample was selected from participants of the 2013 National University Sport Games, 400 copies of questionnaires handed out, with 308 samples were valid, and the retrieve rate was $77 \%$.

\subsection{Instrument}

The questionnaires with 32 service questions were formed according to Ko and Pastore [29], in which contained four factors: program quality, interaction quality, outcome quality, physical environment quality, for recreational sport industry, and Chung [39] used the questionnaires in National Universidad Sports Games, and also according to the situation of the host university for National University Sport Games with the 5-point Likert scale from 1 (strongly disagree) to 5 (strongly agree). Three sections of questionnaires were: demographic data, importance of service quality, and performance of service quality.

\subsection{Data Analyses}

SPSS 20.0 for Windows was applied for descriptive statistics, item analysis, factor reductions, reliability and validity. 
Table 1. Factor analysis of service quality for National University Sport Games in Taiwan

\begin{tabular}{|c|c|c|c|c|c|}
\hline & Item Content & $\begin{array}{c}\text { F1 } \\
\text { Facility \& } \\
\text { Environment }\end{array}$ & $\begin{array}{c}\text { F2 } \\
\text { Interpersonal } \\
\text { Interaction }\end{array}$ & $\begin{array}{c}\text { F3 } \\
\text { Competition } \\
\text { Planning }\end{array}$ & $\begin{array}{c}\text { F4 } \\
\text { Staffs }\end{array}$ \\
\hline 29. & The games provide safety plan & .762 & & & \\
\hline 27. & The games provide good facilities & .744 & & & \\
\hline 28. & The games provide good equipment & .720 & & & \\
\hline 30. & The games provide good facility directory & .692 & & & \\
\hline 26. & The games provide good atmosphere & .680 & & & \\
\hline 32. & $\begin{array}{l}\text { The games provide service center (water } \\
\text { supply, medical station, rest area etc.) }\end{array}$ & .590 & & & \\
\hline 31. & The games provide clean facilities & .511 & & & \\
\hline 23. & Attend the games can interact with others & & .794 & & \\
\hline 24. & $\begin{array}{l}\text { Attend the games can improve the } \\
\text { relationship with other participants }\end{array}$ & & .792 & & \\
\hline 22. & $\begin{array}{l}\text { Attend the games, help me to enhance social } \\
\text { association }\end{array}$ & & .752 & & \\
\hline 25. & $\begin{array}{l}\text { Attend the games, help me to improve } \\
\text { personal fulfillment }\end{array}$ & & .692 & & \\
\hline 20. & Attend the games will make me happy & & .607 & & \\
\hline 21. & I like to participate this sport games & & .580 & & \\
\hline 18. & $\begin{array}{l}\text { After participation, help me to improve sport } \\
\text { skill }\end{array}$ & & .571 & & \\
\hline 19. & $\begin{array}{l}\text { After participation, help me to improve sport } \\
\text { knowledge }\end{array}$ & & .559 & & \\
\hline 17. & $\begin{array}{l}\text { Attend the games, can help me to improve } \\
\text { personal fitness }\end{array}$ & & .533 & & \\
\hline 3. & Competition Arrangement is proper & & & .739 & \\
\hline 1. & Hosting dates are appropriate & & & .703 & \\
\hline 2. & Mufti-Events offered for selection & & & .672 & \\
\hline 5. & Competition Information is easy to reach & & & .617 & \\
\hline 4. & Registration is very convenience & & & .595 & \\
\hline 9. & Non-competition programs are amazing & & & .562 & \\
\hline 6. & Competition event attracts me to participate & & & .484 & \\
\hline & Staffs aggressively ask participants' demand & & & & .725 \\
\hline & Staffs can solve the problem successfully & & & & .677 \\
\hline 13. & Friendly service staffs & & & & .676 \\
\hline & Accurate performance by official and judges & & & & .671 \\
\hline & Professional officials and judges & & & & .516 \\
\hline & Information update quickly and accurately & & & & .503 \\
\hline & Easy to contact the host & & & & .474 \\
\hline & Offered complete information & & & & .466 \\
\hline & Staffs can provide completely instructions & & & & .410 \\
\hline Eig & nvalue & 16.59 & 1.67 & 1.43 & 1.22 \\
\hline$\%$ & ariance & 51.85 & 5.23 & 4.45 & 3.80 \\
\hline$\%$ a & ccumulation & 51.85 & 57.08 & 61.53 & 65.34 \\
\hline Cro & abach's $\alpha$ & .909 & .936 & .892 & .919 \\
\hline Tot & 1 scale Cronbach's $\alpha$ & & .969 & & \\
\hline
\end{tabular}

\subsubsection{Item analysis}

Item and total correlation and t-test were used for item analysis, service quality survey t-test of importance ranged from 9.38 19.69 with $\mathrm{p}<.05$ significant level; and, item and total correlation range between $0.60 \sim 0.82$; while service quality survey t-test of performance ranged from 8.69 13.89 with $\mathrm{p}<.05$ significant level; in addition, item and total correlation range between $0.60 \sim 0.86$; in which all items were 
higher than 0.3 , those indicated that all items had fulfilled the discriminative power, and all of questions kept for the study.

\subsubsection{Factor analysis}

Thirty two questions of service quality were undertaken for factor reduction, KMO value of 0.959 and Bartlett value of 7894.817 and significant level of .000 , and extract eigenvalue higher than 1 with varimax method and factor loading above 0.4 . There were four factors in which named as "facility and environment, interpersonal interaction, competition planning, and staffs," and the cumulative variance was $65.34 \%$.

\subsubsection{Reliability and validity analyses}

Cranbach's $\alpha$ was used for test the reliability. Four factors of service quality showed that each Cranbach's $\alpha$ were "facility and environment" 0.909 , "interpersonal interaction" 0.936, "competition planning" 0.892 , and "staffs" 0.919 , total scale of Cronbach's $\alpha$ 0.969; all factors exceeding $\alpha$ value of .70 recommended by Nunnally and Bernstein [45], please see Table 1 .

To test the validity of service quality of National University Sport Games were consulting from Ko and Pastore [29], and Chung [39]; therefore, the questionnaires had content validity. Furthermore, cumulative variance of service quality $65.34 \%$, in which meant the questionnaire had well constructs validity.

\section{Result}

\subsection{Participant Profile}

The results of demographic data were: 194 males (63\%) and 114 females (37\%); participation division were: 201 in open division (I) (65.3\%), those athletes whom was placed top 8 in the National High School Sport Games or majored in the department of Physical Education or relative field in universities or colleges; and 102 in regular division (II)
(33.1\%), for those do not fit in open division.

\subsection{Importance and Performance Analysis}

IPA was used to unfold of each question average with overall average that will fall into which quadrant to offer the suggestions for managerial unit to improve its service quality (Hollenhorst, Olson, \& Fortney, [21]). The average of importance and performance were 4.03 and 3.61 respectively, please see figure 2 . The result of the research indicated that there were 13 items in quadrant I, such as in the factor III competition planning, "competition event attracts me to participate", factor IV staff "professional officials and judges", "friendly service staffs", "accurate performance by officials and judges", "staffs can solve the problem successfully", factor II interpersonal interaction, "after participation, help me to improve sport skill", "after participation, help me to improve sport knowledge", "attend the games will make me happy", "I like to participate this sport games", "attend the games, help me to improve personal fulfillment ", and factor I, "good atmosphere", "good equipment", "service center (water supply, medical station, rest area etc.)"; in which meant that both participants rank in high importance and the management unit also did in high performance, thus the unit should keep up those good service. 4 items were in quadrant II, participants required high in importance, but the management did the performance low, all in factor I of facility and equipment, "good facilities", "safety plan", "good facility directory", "clean facilities", therefore, the management unit should concentrate in those services for improvement; 11 items were in quadrant III, both participants asked for low importance, the management unit performance also low, the unit can do those service without much pressure; 4 items were in quadrant IV, participants replied with low importance, while high in performance from the management unit, thus, the unit should reduce resources for those services.

\begin{tabular}{|c|c|c|}
\hline \multirow{2}{*}{$\begin{array}{c}\text { Importance } \\
\text { Average } 4.03\end{array}$} & $\begin{array}{c}\text { II } \\
\text { Concentrate Here } \\
\text { (High importance/ Low performance) } \\
\text { Q27 (4.11; 3.58); Q29 }(4.10 ; 3.59) \\
\text { Q30 (4.08; 3.53); Q31 (4.16; 3.59) }\end{array}$ & $\begin{array}{c}\text { I } \\
\text { Keep up the good work } \\
\text { (High importance/ High performance) } \\
\text { Q6 }(4.06 ; 3.71) ; \quad \text { Q11 }(4.19 ; 3.75) \\
\text { Q12 }(4.15 ; 3.70) ; 13(4.12 ; 3.72) \\
\text { Q15 }(4.03 ; 3.61) ; \quad \text { Q18 }(4.08 ; 3.80) \\
\text { Q19 }(4.11 ; 3.79) ; \quad \text { Q20 }(4.14 ; 3.70) \\
\text { Q21 }(4.10 ; 3.84) ; \quad \text { Q25 }(4.09 ; 3.67 \\
\text { Q26 (4.08; 3.68); Q28 }(4.12 ; 3.63) \\
\text { Q32 }(4.21 ; 3.65)\end{array}$ \\
\hline & $\begin{array}{c}\text { III } \\
\text { Low priority } \\
\text { (Low importance/ Low performance) } \\
\text { Q1 (3.90; 3.12); Q2 }(3.87 ; 3.51) \\
\text { Q3 }(3.98 ; 3.30) ; \text { Q4 }(3.89 ; 3.59) \\
\text { Q5 }(3.98 ; 3.51) ; \text { Q7 }(3.78 ; 3.45) \\
\text { Q8 (4.00; 3.60); Q9 }(3.73 ; 3.42) \\
\text { Q10 }(3.95 ; 3.45) ; \text { Q14 }(4.02 ; 3.50) \\
\text { Q16 }(3.94 ; 3.54)\end{array}$ & $\begin{array}{c}\text { IV } \\
\text { Possible overkill } \\
\text { (Low importance/ High performance) } \\
\text { Q17 (3.96; 3.66); Q22 }(3.99 ; 3.69) \\
\text { Q23 (3.99; 3.74); } \text { Q24 }(3.97 ; 3.77)\end{array}$ \\
\hline
\end{tabular}

Figure 2. IPA of service quality for National University Sport Games in Taiwan 


\section{Discussion and Conclusions}

Within the certain amount of budget and limitation of human resource, IPA is a low-cost, simple, and effective analysis technique (Zhang \& Chow, [47]; Levenburg \& Magal, [44]), it was suitable for discovering the strengths and weaknesses of products or services to help the managerial unit to identify the prior improving service quality attributes (Deng \& Lee, [48]), and help the management units to provide a proper decision and strategy effectively to reduce weaknesses and prevent resource waste (Chapman, [34]; Cheron et. al., [35]; Raymond \& Chu, [36]; Martilla \& James, [32], Crompton \& Duray, [49]; Sampson \& Showalter, [50]; Skok et al., [51]). There were four questions dropped in the quadrant II, for instance, "the games provide good facilities, safety plan, good facility directory, and clean facilities", those items must be well-maintained to reach the service quality for National University Sport Games, in order to offer athletes with safety environment to improve their performance in the competition. Athletes had trained so hard through times and they expected to have good performance in the biggest sport competition of the year, thus they addressed high importance for safety environment and facility. Furthermore, the host university or college each year could request the grant funds from Ministry of Education in Taiwan to repair or maintain the sport complex, arrange schedule for cleaning restroom and trash around the facility rest area, event insurance coverage also paid by the host unit for the competition environmental safety for athletes and staffs as well. Questions in the Quadrant I, such as "competition event attracts me to participate", "professional officials and judges", "accurate performance by official and judges", "friendly service staffs", and so on, were the strengths of the unit and should keep up the good work; whereas those items were in sufficiency will lead to satisfaction, while insufficiency leads to dissatisfaction (Kuo, Chen, \& Deng, [52]). Quadrant III was low priority and quadrant IV was possible overkill, thus, and the unit did not need to pay much attention in these questions, just fulfilled the basic demand for the games.

The results of the study could only provide the management units of the National University Sport Games in Taiwan for improvement its service quality in the future; however, the results might not suitable to other sport events directly. Therefore, the author recommends that further researches can do in different sport events, such as National Sport Games, National Junior and High School Sport Games, and ball games (ex: volleyball, basketball, etc.) to unfold participants' perceptions of demand to enhance service quality in various sport competitions. Furthermore, IPA can combine with Kano model, two-dimensional quality, to discuss the service quality in sport competitions for the management units to offer better programs or strategies to improve service quality.

\section{REFERENCES}

[1] Cronin, J. J. \& Taylor, S. A. (1992). Measuring service quality: A reexamination and extension. Journal of Marketing, 56(3), $55-68$.

[2] Oliver, R.L. (1993). A conceptual model of service quality and service satisfaction: compatible goals, different concepts. In T. A.Swartz, D. E. Bowen, and S. W. Brown (2nd ed.), Advances in Services Marketing and Management: Research and Practice (pp. 65-85). Greenwich, CT: JAI Press.

[3] Spreng, R. A. \& Mackoy, R. D. (1996). An empirical examination of a model perceived service quality and satisfaction. Journal of Retailing, 72, 201-214.

[4] Baker, D. A., \& Crompton, J. L. (2000). Quality, satisfaction and behavioral intentions. Annals of Tourism Research, 27, 785-804.

[5] Cronin, J. J. Brady, M. K. \& Hult, G. T. M. (2000). Assessing the effects of quality, value and customer satisfaction on consumer behavioral intentions in service environments. Journal of Retailing, 76, 193-218.

[6] Petrick, J. F. (2004). The roles of quality, perceived value and satisfaction in predicting cruise passengers' behavioral intentions. Journal of Travel Research, 42, 397-407.

[7] Baloglu, S. (1999). A path analytic model of visitation intention involving information sources, socio-psychological motivations, and destination image. Journal of Travel \& Tourism Marketing, 8, 81-90.

[8] Bigne, E. J., Sanchez, I. M., \& Sanchez, J. (2001). Tourism image, evaluation variables and after purchase behavior: Inter-relationship. Tourism Management, 22, 607-616.

[9] Petrick, J. F., Morais, D. D. \& Norman, W. C. (2001). An examination of the determinants vacationers' intentions to revisit. Journal of Travel Research, 40, 41-48.

[10] Grönroos, C. (1982). An applied service marketing Theory. European Journal of Marketing 16(7), 30-41.

[11] Lewis, R. C. \& Booms, B. (1983). The marketing aspects of service quality. AMA Proceeding, American Marketing Association Chicago, 99-104.

[12] Parasuraman, A., Zeithaml, V. A., \& Berry, L. L. (1985). A conceptual model service quality and its implications for future research. Journal of Marketing, 49(3), 41-50.

[13] Woodside, A.G., Frey, L. L., \& Daly, R.T. (1989). Linking service quality, customer satisfaction, and behavioral intention. Journal of Health Care Marketing, 9, 5-17.

[14] Bolton, R. N., \& Drew, J. H. (1991). A multistage model of customers' assessments of service quality and value. Journal of Customer Research, 17, 375-384.

[15] Shonk, D.J, \& Chelladurai P. (2008). Service quality, satisfaction, and intent to return in event sport tourism. Journal of Sport Management, 22, 587-602.

[16] Caruana, A., Money, A. H. \& Berthon, P. R. (2000). Service quality and satisfaction- the moderating role of value. European Journal of Marketing, 34(11/12), 1338-1352.

[17] Lehtinen, U. \& Lehtinen, J. (1991). Two approaches to service quality dimensions. The Service Industries Journal, 11, 287-303. 
[18] Gronroos, C. (1988). Service quality: The six criteria of good perceived service quality. Review of Business, 9(3), 10-13.

[19] Lewis, B. R. \& Vincent, M. (1990). Defining and measuring the quality of consumer service. Marketing Intelligence \& Planning, 8, 11-17.

[20] Tang, L. Y., \& Hu, A. H. (1996). Development of a satisfaction model. Chiao Da Management Review, 16(1), $55-74$.

[21] Alexandris, K., Zahariadis, P., Tsorbatzoudis, C., \& Grouios, G. (2004). An empirical investigation of the relationships among service quality, customer satisfaction and psychological commitment in a health club context. European Sport Management Quarterly, 4(1), 36-52.

[22] Bernhardt, K., Donthu, N., \& Kennett, P. (2000). A longitudinal analysis of satisfaction and profitability. Journal of Business Research, 47, 161-171.

[23] Ganesh, J., Arnold, M. J. \& Reynolds, K. E. (2000). Understanding the customer base of service providers: An examination of the differences between switchers and stayers. Journal of Marketing 64, 65-87.

[24] Howat, G., Murray, D., \& Crilley, G. (1999). The relationships between service problems and perceptions of service quality, satisfaction, and behavioral intentions of Australian public sports and leisure centre customers. Journal of Park and Recreation Administration, 17(2), 42-64.

[25] Murray, D., \& Howat, G. (2002). The relationships among service quality, value, satisfaction, and future intentions of customers at an Australian Sports and Leisure Centre. Sport Management Review, 5, 25-43.

[26] Voss, C. A., Roth, A. V., \& Rosenzweig, E. D., Blackmon, K. (2004). A tale of two countries' - conservatism, service quality, and feedback on customer satisfaction. Journal of Service Research, 6(3), 212-230

[27] Lu, R. S., Chang, C. M., \& Huang, F. M. (2005). The formulation of the service quality scale of racing: A case study of Terry Fox Run. Sports \& Exercise Research, 7(2), 59-73.

[28] Tsitskari, E., Tsiotras, D., \& Tsiotras, G. (2006). Measuring service quality in sport services. Total Quality Management, 17(5), 623-631

[29] Ko, Y. J. \& Pastore, D. L. (2005). A hierarchical model of service quality for the recreational sport industry. Sport Marketing Quarterly, 14, 84-97.

[30] Tsuji, Y., Bennett, G., \& Zhang, J. (2007). Consumer satisfaction with an action sports event. Sport Marketing Quarterly, 16, 199-208.

[31] Moon, K., Ko, Y. J., Connaughton, D., \& Lee, J. H. (2013). A mediating role of destination image in the relationship between event quality, perceived value, and behavioral intention. Journal of Sport and Tourism, 18(1), 49-66.

[32] Martilla, J. A. \& James, J. C. (1977). Importance performance analysis. Journal Marketing, 41(1), 77-79.

[33] Haemoo, O. (2001). Revisiting importance - performance analysis. Tourism Management, 22(6), 617-627.

[34] Chapman, R. G. (1993). Brand performance comparatives.Journal of Product and Brand Management, 2(1), 42-50.
[35] Cheron, E. J, McTavish, R., Perrien, J. (1989). Segmentation of bank commercial markets. International Journal of Bank Marketing, 7(6), 25-30.

[36] Raymond, K. S. \& Chu, T. C. (2000). An importance-performance analysis of hotel selections factors in the Hong Kong hotel industry: A camparison of business and leisure travelers. Tourism Management, 21, 363-377.

[37] Marr, J. W, (1986). Letting the customer be the judge of quality. Quality progress, 19(10), 46-49.

[38] Lu, R. S., \& Chen, H. C. (2007). A study of service quality on the 2004 Peng-Hu First International Chinese Marathon Event. Journal of Taiwan Society for Sport Management, 5, 236-259.

[39] Chung, C. C. (2008). The relationship between the service quality and behavioral intention in National Universidad Sports Games. Journal of Sport and Recreation Management, 5(1), 73-83.

[40] Chen, R. J., Chen, M. F., \& Lee. H. C. (2012). The relationships among service quality, satisfaction and behavioral intentions in cycling competition. Leisure \& Exercise, 11, 93-103.

[41] Chang, C. Y., Lai, H. S., \& Wang, C. C. (2014). Using the IPA method to evaluate visits' satisfaction of Lukang area. Journal of Leisure, Tourism, Sport, \& Health, 5(1), 70-92.

[42] Liao, W. R. (2013). Using importance-performance analysis (IPA) to assess the quality of service at the Museum of Contemporary Art, Taipei. Technology Museum Review, 17(1), 5-26.

[43] Ho, P. C., Chung, K. H. \& Chang, H. H. (2013). Applying the Kano two-dimensional model and important performance analysis to explore the quality attributes of Junior Secondary Education with an analysis of the parents' points of view. Yu Da Academic Journal, 36, 143-160.

[44] Levenburg, N. M., \& Magal, S. R. (2005). Applying importance-performance analysis to evaluate e-business strategies among small firms. e-Service Journal, 3(3), 29-48.

[45] Nunnally. J. C, \& Bernstein., I. H. (1994). Psychometric theory (3th ed.). New York, NY: McGraw-Hill.

[46] Hollenhorst, S., Olson, D. \& Fortney, R. (1992). Use of importance-performance analysis to evaluate State Park Cabins: the case of the West Virginia State Park System. Journal of Park and Recreation Administration, 10(1), 1-11.

[47] Zhang, H.Q., \& Chow, I. (2004). Application of importance-performance model in tour guides' performance: Evidence from mainland Chinese outbound visitors in Hong Kong. Tourism Management, 25(1), 81-91.

[48] Deng, W. J. \& Lee, Y. C. (2007). Applying Kano model and IPA to identify critical service quality attributes for hot springs hotels in Peitou. Journal of Quality, 14(1), 99-113.

[49] Crompton, J. L. \& Duray, N. A. (1985). An investigation of the relative efficacy of four alternative approaches to importance-performance analysis. Journal of the Academy of Marketing Science, 12(4), 69-80.

[50] Sampson, S. E. \& Showalter, M. J. (1999). The performance-importance response function: Observation and implications. The Service Industries Journal, 19(3),1-25. 
[51] Skok, W., Kophamel, A., \& Richardson, I. (2001). Diagnosing information systems success: Importance-performance maps in the health club industry. Information \& Management, 38(7), 409-419.
[52] Kuo, Y. F., Chen, J. Y., \& W. J. Deng. (2007). IPA-Kano model: A new tool for categorizing and diagnosing service quality attributes. Total Quality Management, 23(7), 731-748. 